\title{
Frequency and Risk Factors of Post Banding Ulcer Bleeding Following Endoscopic Variceal Ligation in Patients with Liver Cirrhosis
}

\author{
Soha A Elhawari ${ }^{1}$, Emad A Moustafa $^{1}$, Tarik I Zaher ${ }^{1}$, Hany M Elsadek ${ }^{2}$, \\ Mahmoud A Abd-Elazeim ${ }^{1}$ \\ ${ }^{I}$ Tropical Medicine Department, Faculty of Medicine, Zagazig University, Egypt \\ ${ }^{2}$ Internal Medicine Department, Faculty of Medicine, Zagazig University, Egypt
}

Corresponding Author Soha A Elhawari

\section{Mobile: \\ $+201064218082$ \\ E mail: \\ sohaelhawary@yahoo. com}

Key words: Endoscopic variceal ligation-EVL; Postbanding ulcer bleeding; Risk factor
Background and aim: Endoscopic variceal ligation (EVL) is one of the best modalities for treatment of esophageal varices. One of the most serious complications after EVL is post-banding ulcer bleeding. In this study, frequency and risk factors of EVL-induced ulcer bleeding were assessed.

Methods: One hundred and twenty six patients with liver cirrhosis subjected to EVL, whether done as prophylactic or therapeutic, were followed up for two weeks for detection of occurrence of postbanding ulcer bleeding. A prospective cohort study was performed comparing the patients that bleed after EVL due to post-banding ulcer (bleeder group, $n=10$ ) with those without this complication (non-bleeder group, $\mathrm{n}=116$ ).

All patients received full medical history taking; complete physical examination; routine laboratory tests; Pelvi-abdominal ultrasonography; Esophago-gastroduodenoscopy (EGD) and EVL; treatment with blood transfusion and pharmacologic agents; re-endoscopy if rebleeding occur after EVL.

Results: Frequency of post-banding ulcer bleeding after EVL in patients who have liver cirrhosis was $7.9 \%$, and its mortality within 14 days follow up was $10 \%$. Reflux esophagitis was found to be a risk factor of post- banding ulcer bleeding $(\mathrm{P}=$ 0.016, OR= 8). Proton pump inhibitor (PPI) may be a protective factor against occurrence of post-banding ulcer bleeding $(\mathrm{P}=0.054)$.

Conclusion: Post-banding ulcer bleeding is an infrequent complication after EVL. Reflux esophagitis is considered an independent risk factor for this complication.

\section{INTRODUCTION}

Esophageal variceal bleeding represents the most vital complication among patients with liver cirrhosis at a rate of 5-15\% per year. Predictors of variceal bleeding include variceal size, red wale sign at endoscopy and Child-Turcotte-Pugh (CTP) class B or $\mathrm{C}$ [1]. In cirrhotic patients, the incidence of varices was found to be $60 \%$ to $80 \%$ with $17 \%$ to $57 \%$ mortality from each variceal bleeding episode [2]. Thus, bleeding prevention from esophageal varices $(\mathrm{EV})$ remains the fundamental in long-term management of patients with liver cirrhosis.

Endoscopic variceal ligation (EVL), either used as therapeutic in emergency or as prophylactic, is one Elhawari et al., Afro-Egypt J Infect Endem Dis 2019; 9(4):252-259

https://aeji.journals.ekb.eg/

http://mis.zu.edu.eg/ajied/home.aspx of the best modalities used in EV treatment [3]. It aims to obliterate the varix by inducing ulceration with scar tissue formation [4]. Although it is considered safe, EVL has few complications [5]. Transient dysphagia, post ligation pain and esophageal stricture formations were the most frequent reported complications [6,7]. Moreover, early rebleeding after EVL (between 24 hour and 14 day) was reported in about $3.6 \%$ to $15 \%$ of patients $[\mathbf{7 , 8 , 9 ]}$. Rebleeding can be fatal, and is mainly resulted from early spontaneous slippage of the rubber bands, before occlusion of the varix with a mature thrombus, leaving an unhealed ulcer $[10,11,12]$. 
In few studies, possible risk factors for postbanding ulcer bleeding have been reported in spite of the significant associated morbidity and mortality [10,13]. Therefore, this research was conducted for assessment of frequency and risk factors of post-banding ulcer bleeding following EVL in patients with liver cirrhosis, in order to minimize post-banding ulcer bleeding.

\section{PATIENTS AND METHODS}

\section{Patients}

The study was carried out in Tropical Medicine and Internal Medicine Departments-Zagazig University, Egypt, from March to November 2017. The study included total number of 126 patients who have liver cirrhosis and subjected to EVL, whether done as prophylactic (primary/secondary) or therapeutic. Patients with history of previous injection sclerotherapy were excluded.

\section{Study design}

Prospective cohort study.

\section{Definitions}

Liver cirrhosis is detected by history of longstanding liver disease; clinical by symptoms \& signs of chronic liver disease; by abdominal ultrasound and; by laboratory investigations (elevated bilirubin, prolonged prothrombin time, presence of varices in Esophago-gastroduodenoscopy) [14].

Early post-banding ulcer bleeding after EVL is defined as endoscopically confirmed active bleeding (spurting or oozing) occurring 24 hour to 14 day after the procedure from an unhealed ulcer that was formed as a result of early spontaneous slippage of the rubber bands $[13,15]$.

\section{Patient management}

- Endoscopic treatment: All the included patients were subjected to esophago-gastroduodenoscopy (EGD) and EVL, either prophylactic or therapeutic.

- Patient with active variceal bleeding was admitted to the ICU. Initial resuscitation was done. Blood volume replacement initiated as soon as possible to maintain systolic blood pressure around $100 \mathrm{mmHg}$ [16]. Medical treatment was given in the form of: intravenous proton pump inhibitor (PPI,40mg) every 12 hours [17]; vitamin $\mathrm{K}$
$10 \mathrm{mg} /$ day IM (at time of admission and continues for 3-5 days) [18]; somatostatin analogue (sandostatin) initial bolus $50 \mu \mathrm{g}$ IV followed by $50 \mu \mathrm{g} /$ hour for 2-5 days [19] and; prophylactic antibiotic (ceftriaxone $1 \mathrm{gm}$ IV /24h) $[\mathbf{1 9 , 2 0 ]}$.

- EGD was performed using a forward-viewing endoscope (PENTAX EPM 3500 Videoscope) under conscious sedation with 5mg Midazolam to all patients [21]. EVL (using 6 shooter Saeed multiband ligatorCook Medical Endoscopy) was done by occluding the protruding varix with elastic rubber rings [15].

- After EVL, the patients were prescribed PPI for 2 weeks, broad-spectrum antibiotics and non-selective beta blocker. Food intake was allowed 12 hour after prophylactic EVL and according to the physician's discretion after therapeutic EVL.

- All patients were followed for14 days with reendoscopy for patients who re-bleed (hematemesis, and/or melena, and/or bloody fluid drained by nasogastric tube) after EVL to confirm that post-banding ulcer was the cause of bleeding.

Two groups of patients were included in the final analysis:

- Bleeder group (group I): comprised 10 patients that bleed after EVL due to postbanding ulcer. We confirmed that there was no other upper gastrointestinal bleeding source.

- Non-bleeder group (group II): comprised 116 patients that did not bleed after EVL.

All patients received the following: a) full medical history taking including age, gender, history of attacks of hematemesis or melena, blood transfusion, cause of liver diseases, history of previous endoscopy or injection sclerotherapy and previous or current history of hepatic encephalopathy; b) complete physical examination with focus on pulse, blood pressure, body temperature and signs of chronic liver disease and portal hypertension; c) laboratory tests comprising complete blood count-CBC, Liver function tests (total and direct bilirubin, total protein and albumin, Aspartate amino Transferase-AST and Alanine amino Transferase-ALT), coagulation profile (prothrombin time-PT and international 
randomization ratio-INR) and, Renal function tests (blood urea and serum creatinine); d) APRI (AST Platelet Ratio Index) score [22]; Modified Child-Turcotte-Pugh (CTP) score [23] and MELD (Model of end stage liver disease) score were estimated [24]; e) Pelviabdominal ultrasonography with stress on liver cirrhosis \& its complications; f) Esophagogastro-duodenoscopy (EGD) and EVL, either prophylactic or therapeutic .At endoscopy, varices were evaluated regarding number of variceal cords; grade of EV [25]; risky signs and; rubber bands number used. Reflux esophagitis was also detected According to Los-Angeles Classification [26].

\section{Statistical Analysis}

Data were checked, entered and analyzed using SPSS statistical package. Data were expressed as mean \pm SD for quantitative variable, number and percentage for qualitative one. Chi-squared (X2) or fisher exact, $t$ test and paired $t$ test were used when appropriate. Logistic regression was used to investigate the relationship between postbanding ulcer bleeding after EVL and other potential predictors that were significant in the univariate analysis. P-value $<0.05$ was considered significant.

\section{RESULTS}

Post-banding ulcer bleeding following EVL was observed in $7.9 \%$ (10 out of 126) of patients (Figure 1). Both groups were matched as regard age and sex. HCV was the commonest cause of cirrhosis (90\%) among all studied patients.

According to occurrence of post-banding ulcer bleeding, there was statistically non-significant difference among both studied groups as regard
CTP classes (A, B and $\mathrm{C})(\mathrm{P}=0.49)$ and MELD score $(\mathrm{P}=0.9)$ (Table 1).

As regard laboratory parameters, there was statistically non-significant relation between all laboratory parameters $(\mathrm{P}>0.05)$ apart from APRI score which shows significant association with occurrence of post-banding ulcer bleeding $(\mathrm{P}=$ 0.006) (Table 2).

As shown in table (3 and 4), abdominal ultrasound findings and endoscopic findings showed statistically significant relation between hepatic focal lesion and reflux esophagitis with the occurrence of post-banding ulcer bleeding $(\mathrm{P}=0.03$ and 0.001 respectively). While, there was statistically non-significant differences among both studied groups as regard indications of EVL $(\mathrm{P}=0.9)$; other ultrasound findings (ascites, splenic span and portal vein diameter; $\mathrm{P}=0.47,0.5$ and 0.17 respectively) and other endosopic findings ( $\mathrm{EV}$ grade, risky signs and number of ligation bands; $\mathrm{P}=0.07,0.3$ and 0.1 respectively).

As regard medical treatment, table (5) showed statistically non-significant relation between occurrence of post-banding ulcer bleeding and RBCs transfusion; PPI use; $\beta$-Blocker use and antibiotic use $(\mathrm{P}=0.4,0.054, \quad 0.48,0.62$ respectively).

Among patients of group I (bleeder group), the post-banding ulcer bleeding occurred within 414 days after EVL, and the mortality rate was $10 \%$ (Table 6).

Table (7) showed that endoscopic reflux esophagitis was a significant predictor of postbanding ulcer bleeding after EVL (odds ratio 8, 95\% confidence interval (1.5-44) Cox \&Snell R2 $=13.2 \%$ ).

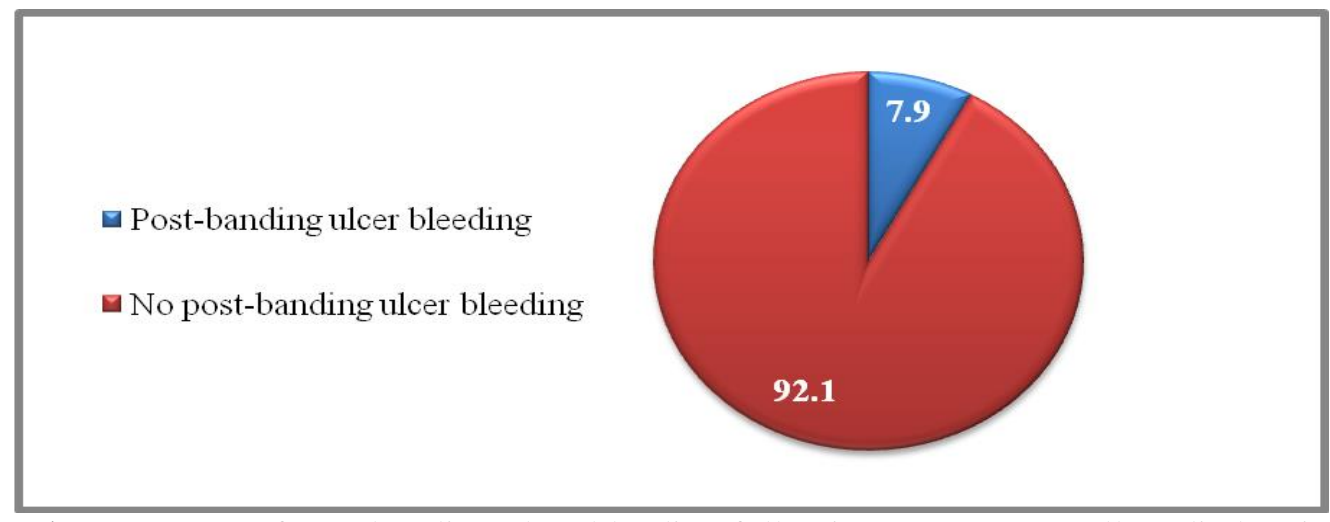

Figure 1: Frequency of post-banding ulcer bleeding following EVL among all studied patients. 
Table 1: Child-Turcotte-Pugh (CTP) classification and MELD score among both studied groups.

\begin{tabular}{|c|c|c|c|c|c|c|}
\hline & \multicolumn{2}{|c|}{ Group I $(n=10)$} & \multicolumn{2}{|c|}{ Group II (n=116) } & \multirow[t]{2}{*}{$\mathbf{P}$} \\
\hline & & $\bar{n}$ & $\%$ & $\mathbf{n}$ & $\%$ & \\
\hline \multirow{3}{*}{$\begin{array}{c}\text { CTP } \\
\text { Classification }\end{array}$} & $\mathbf{A}(\mathrm{n}=29)$ & 2 & $7.0 \%$ & 27 & $93 \%$ & \multirow{3}{*}{$\begin{array}{l}{ }^{+} 0.49 \\
\text { NS }\end{array}$} \\
\hline & $\mathbf{B}(\mathrm{n}=55)$ & 3 & $5.0 \%$ & 52 & $95 \%$ & \\
\hline & $C(n=42)$ & 5 & $12 \%$ & 37 & $88 \%$ & \\
\hline \multicolumn{2}{|l|}{ MELD Score } & & & & & $* * 0.9$ \\
\hline & Mean \pm SD & \multicolumn{2}{|c|}{$15 \pm 6$} & \multicolumn{2}{|c|}{$15 \pm 5$} & NS \\
\hline
\end{tabular}

MELD $=$ Model for end stage liver diseas

Table 2: Laboratory parameters among both studied groups

\begin{tabular}{|c|c|c|c|}
\hline Laboratory Parameters & Group I $(n=10)$ & Group II $(n=116)$ & $\mathbf{P}$ \\
\hline $\begin{array}{l}\text { HB } \\
\text { Mean } \pm \text { SD }\end{array}$ & $9.3 \pm 1.8$ & $9.7 \pm 1.9$ & $\begin{array}{l}* 0.4 \\
\text { NS }\end{array}$ \\
\hline $\begin{array}{l}\text { WBCs } \\
\text { Mean } \pm \text { SD }\end{array}$ & $7.8 \pm 3.2$ & $6.7 \pm 3.6$ & $\begin{array}{c}* * 0.3 \\
\mathrm{NS}\end{array}$ \\
\hline \begin{tabular}{|l} 
Platelets \\
Mean $\pm S D$
\end{tabular} & $122 \pm 62$ & $98 \pm 47$ & $\begin{array}{c}* * 0.2 \\
\mathrm{NS} \\
\end{array}$ \\
\hline $\begin{array}{l}\text { Total protein } \\
\text { Mean } \pm S D\end{array}$ & $5.9 \pm 1$ & $6.1 \pm 0.93$ & $\begin{array}{c}* 0.4 \\
\mathrm{NS}\end{array}$ \\
\hline $\begin{array}{l}\text { Albumin } \\
\text { Mean } \pm \text { SD }\end{array}$ & $2.58 \pm 0.7$ & $2.6 \pm 0.6$ & $\begin{array}{l}* 0.7 \\
\mathrm{NS}\end{array}$ \\
\hline $\begin{array}{l}\text { INR } \\
\text { Mean } \pm \text { SD }\end{array}$ & $1.6 \pm 0.4$ & $1.5 \pm 0.33$ & $\begin{array}{l}* 0.3 \\
\text { NS }\end{array}$ \\
\hline \begin{tabular}{|l} 
ALT \\
Mean \pm SD \\
\end{tabular} & $40 \pm 35$ & $41 \pm 30$ & $\begin{array}{c}* * 0.6 \\
\text { NS }\end{array}$ \\
\hline $\begin{array}{l}\text { AST } \\
\text { Mean } \pm \text { SD }\end{array}$ & $58 \pm 41$ & $57 \pm 35$ & $\begin{array}{c}* * 0.9 \\
\mathrm{NS}\end{array}$ \\
\hline $\begin{array}{l}\text { Total bilirubin } \\
\text { Mean } \pm \text { SD }\end{array}$ & $1.7 \pm 1.7$ & $2.9 \pm 4$ & $\begin{array}{l}* * 0.07 \\
\text { NS }\end{array}$ \\
\hline $\begin{array}{l}\text { Direct bilirubin } \\
\text { Mean } \pm \text { SD }\end{array}$ & $1.1 \pm 1.3$ & $1.9 \pm 3.5$ & $\begin{array}{l}* * 0.29 \\
\text { NS }\end{array}$ \\
\hline $\begin{array}{l}\text { S. Creatinine } \\
\text { Mean } \pm S D\end{array}$ & $1.2 \pm 0.7$ & $1.1 \pm 0.5$ & $\begin{array}{l}* * 0.8 \\
\text { NS }\end{array}$ \\
\hline $\begin{array}{l}\text { APRI score } \\
\text { Mean } \pm \text { SD }\end{array}$ & $1.4 \pm 0.77$ & $0.88 \pm 0.67$ & $\begin{array}{c}* * 0.006 \\
\text { HS }\end{array}$ \\
\hline
\end{tabular}

* t test $* *$ Man-Whitnney test

APRI= AST to platelet ratio index

Table 3: Abdominal ultrasound findings among both studied groups.

\begin{tabular}{|c|c|c|c|c|c|c|}
\hline \multicolumn{2}{|c|}{ Ultrasound findings } & \multicolumn{2}{|c|}{ Group I(n=10) } & \multicolumn{2}{|c|}{ Group II $(\mathrm{n}=116)$} & \multirow[t]{2}{*}{$\mathbf{P}$} \\
\hline & & $\mathbf{n}$ & $\%$ & $\mathbf{n}$ & $\%$ & \\
\hline \multirow[t]{2}{*}{ Focal lesion } & Yes $(n=26)$ & 5 & $19 \%$ & 21 & $81 \%$ & \multirow{2}{*}{$\begin{array}{c}{ }^{\mathrm{f}} 0.03 \\
\mathbf{S} \\
++4.5(1.2-17)\end{array}$} \\
\hline & No $(n=100)$ & 5 & $5.0 \%$ & 95 & $95 \%$ & \\
\hline \multirow[t]{4}{*}{ Ascites } & Absent $(\mathrm{n}=46)$ & 2 & $4.0 \%$ & 44 & $96 \%$ & \multirow{4}{*}{$\begin{array}{l}{ }^{+} 0.47 \\
\text { NS }\end{array}$} \\
\hline & Mild $(n=20)$ & 2 & $10 \%$ & 18 & $90 \%$ & \\
\hline & Moderate $(\mathrm{n}=21)$ & 1 & $5.0 \%$ & 20 & $95 \%$ & \\
\hline & Tense $(n=39)$ & 5 & $13 \%$ & 34 & $87 \%$ & \\
\hline \multicolumn{2}{|c|}{ Splenic span $(\mathrm{cm})$} & & & & & $* 0.5$ \\
\hline & Mean \pm SD & & \pm 1.1 & \multicolumn{2}{|c|}{$16.6 \pm 1.3$} & NS \\
\hline \multicolumn{2}{|l|}{ PVD $(\mathrm{mm})$} & & & & & $* 0.17$ \\
\hline & Mean \pm SD & & $8 \pm 4$ & \multicolumn{2}{|c|}{$14.9 \pm 1.8$} & NS \\
\hline \multicolumn{2}{|c|}{$\begin{array}{l}{ }^{++} \text {odds ratio } 95 \% \text { confidence interval } \\
\mathrm{PVD}=\text { Portal vein diameter }\end{array}$} & \multicolumn{2}{|c|}{$\begin{array}{l}{ }^{\mathrm{T}} \text { Fisher exact test } \\
\mathrm{S}=\text { Significant }\end{array}$} & \multicolumn{2}{|c|}{$\begin{array}{l}\text { Chi-square test } \\
\text { NS= Non significant }\end{array}$} & \\
\hline
\end{tabular}

Elhawari et al., Afro-Egypt J Infect Endem Dis 2019; 9(4):252-259

https://aeji.journals.ekb.eg/

http://mis.zu.edu.eg/ajied/home.aspx 
Table 4: Indications of EVL and endoscopic findings among both studied groups.

\begin{tabular}{|c|c|c|c|c|c|c|}
\hline & \multicolumn{2}{|c|}{ Group I $\mathbf{I}(\mathrm{n}=10)$} & \multicolumn{2}{|c|}{ Group II $(\mathrm{n}=116)$} & \multirow[t]{2}{*}{$\overline{\mathbf{P}}$} \\
\hline & & $\mathbf{n}$ & $\%$ & $\mathbf{n}$ & $\%$ & \\
\hline \multirow{3}{*}{$\begin{array}{c}\text { Indications of } \\
\text { EVL }\end{array}$} & Therapeutic $(\mathrm{n}=42)$ & 6.0 & $14 \%$ & 36 & $86 \%$ & \multirow{3}{*}{$\begin{array}{l}{ }^{+} 0.9 \\
\text { NS }\end{array}$} \\
\hline & $\mathbf{1}^{\mathrm{ry}}$ prophylaxis $(\mathrm{n}=25)$ & 0.0 & $0.0 \%$ & 25 & $100 \%$ & \\
\hline & $\mathbf{2}^{\mathrm{ry}}$ prophylaxis $(\mathrm{n}=59)$ & 4.0 & $7.0 \%$ & 55 & $93 \%$ & \\
\hline \multicolumn{7}{|c|}{ Endoscopic findings } \\
\hline Reflux & Present $(n=12)$ & 5.0 & $42 \%$ & 7 & 58 & 0.001 \\
\hline Esophagitis & Absent $(n=114)$ & 5.0 & $4.0 \%$ & 109 & 96 & $\begin{array}{c}\text { HS } \\
{ }^{++} 15.5(3.6-67)\end{array}$ \\
\hline \multirow[t]{3}{*}{ EV grade } & Grade2 $(n=44)$ & 1.0 & $2.0 \%$ & 43 & $98 \%$ & ${ }^{+} 0.07$ \\
\hline & Grade3 $(n=70)$ & 9.0 & $13 \%$ & 61 & $87 \%$ & NS \\
\hline & Grade4 $(n=12)$ & 0.0 & $0.0 \%$ & 12 & $100 \%$ & \\
\hline \multirow{2}{*}{ Risky signs } & Present $(n=88)$ & 8 & $9.0 \%$ & 80 & $91 \%$ & 0.3 \\
\hline & Absent $(\mathrm{n}=38)$ & 2 & $5.0 \%$ & 36 & $95 \%$ & $\mathrm{NS}$ \\
\hline \multirow{4}{*}{$\begin{array}{l}\text { Number of } \\
\text { ligation bands }\end{array}$} & Three bands $(n=35)$ & 1 & $3.0 \%$ & 34 & $97 \%$ & ${ }^{+} 0.1$ \\
\hline & Four bands $(n=46)$ & 2 & $4.0 \%$ & 44 & $96 \%$ & NS \\
\hline & Five bands $(n=35)$ & 6 & $17 \%$ & 29 & $83 \%$ & \\
\hline & Six bands $(n=10)$ & 1 & $10 \%$ & 9 & $90 \%$ & \\
\hline
\end{tabular}

${ }_{++}^{+}$odds ratio (95\% confidence interval)

$\mathrm{EVL}=$ endoscopic variceal ligation

${ }^{+}$Chi-square test

${ }^{\mathrm{f}}$ Fisher exact test

$\mathrm{EV}=$ Esophageal varices

Table 5: RBCs transfusion and post-banding medical treatment among both studied groups.

\begin{tabular}{|c|c|c|c|c|c|c|}
\hline & & \multicolumn{2}{|c|}{ Group $\mathbf{I}(\mathrm{n}=10)$} & \multicolumn{2}{|c|}{ Group II $(n=116)$} & \multirow[t]{2}{*}{$\mathbf{P}$} \\
\hline & & $\mathbf{n}$ & $\%$ & n & $\%$ & \\
\hline \multirow[t]{2}{*}{ RBCs transfusion } & Yes $(n=21)$ & 3 & $14 \%$ & 18 & 86 & \multirow{2}{*}{$\begin{array}{l}{ }^{\mathrm{f}} 0.4 \\
\mathrm{NS}\end{array}$} \\
\hline & No $(n=105)$ & 7 & $7.0 \%$ & 98 & 93 & \\
\hline \multicolumn{7}{|l|}{ Treatment } \\
\hline \multirow[t]{2}{*}{ PPI } & Yes $(n=114)$ & 7 & $6.0 \%$ & 107 & $94 \%$ & \multirow{2}{*}{$\begin{array}{c}0.054 \\
\text { NS }\end{array}$} \\
\hline & No $(n=12)$ & 3 & $25 \%$ & 9 & $75 \%$ & \\
\hline \multirow[t]{2}{*}{$\beta$-Blocker } & Yes $(n=66)$ & 5 & $8.0 \%$ & 61 & $92 \%$ & \multirow{2}{*}{$\begin{array}{l}0.48 \\
\text { NS }\end{array}$} \\
\hline & No $(n=70)$ & 5 & $7.0 \%$ & 65 & $93 \%$ & \\
\hline \multirow[t]{2}{*}{ Antibiotic } & Yes $(n=75)$ & 6 & $8.0 \%$ & 69 & $92 \%$ & \multirow{2}{*}{$\begin{array}{l}{ }^{\mathrm{f}} 0.62 \\
\text { NS }\end{array}$} \\
\hline & No $(n=51)$ & 4 & $8.0 \%$ & 47 & $92 \%$ & \\
\hline
\end{tabular}

${ }_{\mathrm{f}}^{\mathrm{f}}$ Fisher exact test

$\mathrm{PPI}=$ Proton pump inhibitor

Table 6: Timing of post-banding ulcer bleeding and mortality rate among group I (bleeder group).

\begin{tabular}{|c|c|c|}
\hline \multicolumn{3}{|c|}{ Group I (n=10) } \\
\hline Time of post banding ulcer bleeding (days) & \multicolumn{2}{|c|}{$10(4-14)$} \\
\hline Median (Range) & \multicolumn{2}{|c|}{$9.2 \pm 3.7$} \\
\hline Mean \pm SD & $\mathbf{n}$ & $\mathbf{\%}$ \\
\hline Mortality rate after post-banding ulcer bleeding & 1 & $10 \%$ \\
\hline Died & 9 & $90 \%$ \\
\hline Survival & 9 & \\
\hline
\end{tabular}

Table 7: Logestic regression to predict risk factors of post-banding ulcer bleeding after EVL.

\begin{tabular}{|c|c|c|c|}
\hline Variables & P & OR & $\mathbf{9 5 \%}$ CI \\
\hline APRI score & 0.4 & 1.45 & $0.6-3.5$ \\
\hline Hepatic Focal lesion & 0.151 & 3.2 & $0.7-15$ \\
\hline Reflux Esophagitis & 0.016 & 8 & $1.5-44$ \\
\hline
\end{tabular}

OR $=$ Odds ratio

Elhawari et al., Afro-Egypt J Infect Endem Dis 2019; 9(4):252-259

https://aeji.journals.ekb.eg/

http://mis.zu.edu.eg/ajied/home.aspx 


\section{DISCUSSION}

Endoscopic variceal ligation (EVL), either therapeutic or prophylactic, is an effective method for prevention and management of variceal bleeding. EVL has many complications most of them are simple and transient [5]. Postbanding ulcer bleeding after EVL is relatively uncommon but severe complication. Few studies reported the possible risk factors of this complication in cirrhotic patients without allocating the source of bleeding by endoscopy $[10,13]$. This work was done to assess frequency and risk factors of post-banding ulcer bleeding following EVL in patients with liver cirrhosis in order to minimize post-banding ulcer bleeding.

In this study, frequency of post-banding ulcer bleeding following EVL in cirrhotic patients was found to be $7.9 \%$. This result is similar to a report of $7.7 \%$ by Cho et al.[15] who determined that the source of rebleeding was post-banding ulcer. On the other hand, this result is higher than previously published rates by Petrasch et al. and Sinclair et al.[8,27] who reported rates of $3.6 \%$ and $2.8 \%$ respectively. While, Shendy et al. [28] estimated that rate of early rebleeding after EVL was $11 \%$, but in that study source of rebleeding was not determined by endoscopy.

In previous studies, poor liver condition (CTPclass $\mathrm{C}$, high MELD score) was identified as a predictive factor of rebleeding in cirrhotic patients [9,27,28,29]. Reduced coagulation ability, increased vascular fragility and a large extension of submucosal esophageal varices (induced by portal hypertension) might explain the importance of bleeding from post-banding ulcer without effective local thrombosis. In contrast, this study failed to find (from table 1) a statistically significant relation between CTP classess $(\mathrm{P}=0.49)$ or MELD score $(\mathrm{P}=0.9)$ and occurrence of post-banding ulcer bleeding. This may related to past endemicity of bilharziasis in Egypt which causes more vascular decompensation than cellular decompensation, so it is represented by more increase in portal hypertension than decrease in synthetic functions which affect Child and MELD score.

From table 2, the univariate analysis demonstrated significant association between high APRI score and occurrence of post-banding ulcer bleeding $(\mathrm{P}=0.006)$. This is in agreement with Vanbiervliet et al.[10] who found that high APRI score is an independent risk factor of postbanding ulcer bleeding; while Cho et al.[15] found that there is non-significant relation between them. This high APRI score may be attributed to the high AST level that indicates significant cirrhosis and low platelets that leads to defect in haemostasis.

Furthermore, the present study showed statistically significant relation between presence of hepatic focal lesions detected by ultrasonography and occurrence of post-banding ulcer $(\mathrm{P}=0.03)$ (from table 3$)$. This may be due to portal vein thrombosis associated with hepatic focal lesions that cause more increase in portal pressure. This is in contrast to $\mathrm{Xu}$ et al.[30] which found that there is non-significant relation between hepatic focal lesions and occurrence of post-banding ulcer bleeding $(\mathrm{P}=0.67)$. Although in multivariate analysis (from table 7), it was found that high APRI score and presence of hepatic focal lesions are not independent risk factors of post-banding ulcer bleeding ( $\mathrm{P}=0.4$ and 0.151 respectively).

We also stressed in this study on the local factors that may predispose to post-banding ulcer bleeding and it was found that (from table 4), there was statistically significant relation between presence of reflux esophagitis by endoscopy and occurrence of post-banding ulcer bleeding $(\mathrm{P}=0.001)$ which confirmed by the multivariate analysis (from table 7) to be an independent risk factor $(\mathrm{P}=0.016)$. This is consistent with Vanbiervliet et al.[10] that showed statistically significant relation between reflux esophagitis and post-banding ulcer bleeding $(\mathrm{P}=0.011)$. Also, Sinclair et al.[27] found that reflux esophagitis is a modifiable risk factor for EVL induced ulcer bleeding $(\mathrm{P}=0.071)$. These findings strongly suggest that early slippage of the rubber band and post-banding ulcer bleeding may related to the mucosal damages induced by the acid exposure of the lower part of the esophagus

As regard post-banding medical treatment (from table 5), there was non-significant relation between occurrence of post-banding ulcer bleeding and PPI use after EVL $(\mathrm{P}=0.054)$. However, bleeding was more among patients who didn't use PPI ( $25 \%$ vs. $6 \%$ in patients used PPI). So, PPI administration after EVL may have a protective effect against post-banding ulcer bleeding. This could be explained by the improvement of reflux esophagitis that was shown to be a risk factor of post-banding ulcer bleeding. This result is consistent with Shaheen

Elhawari et al., Afro-Egypt J Infect Endem Dis 2019; 9(4):252-259

https://aeji.journals.ekb.eg/

http://mis.zu.edu.eg/ajied/home.aspx 
et al.[31] who found that pantoprazole reduces the size of post-banding ulcers after EVL. Also, Kang et al.[32] concluded that non-use of PPI was independent risk factor for bleeding after prophylactic EVL $(\mathrm{P}=0.002)$. On the other hand, Vanbiervliet et al.[10] and Sinclair et al.[27] found that PPI use was not associated with reduced risk of bleeding $(\mathrm{P}=0.69$ and 0.747 respectively).

As regard mortality rate (from table 6), this study showed that the mortality rate in patients who developed post-banding ulcer bleeding was $10 \%$ (1 patient died out of 10 patients) in comparison to a mortality rate of $52 \%$ by Vanbiervliet et al. [10] and a mortality rate of $28 \%$ by Sinclair et al. [27]. The patient who died suffered from a massive bleeding that lead to death despite an effective replacement therapy. This low mortality rate may be due to short period of follow up (14 days follow up after EVL) in comparison to 2 months follow up in Vanbiervliet et al.[10] and 4 weeks follow up in Sinclair et al.[27].

A limitation of our study that might affect statistical analysis was the relatively few cases of post-banding ulcer bleeding following EVL (10 out of 126 patient), which may related to the short follow up period (14 days) after EVL

\section{CONCLUSSION}

This prospective cohort study and its results revealed that post-banding ulcer bleeding following EVL is an infrequent complication in cirrhotic patients (rate of ulcer bleeding following EVL is $7.9 \%$ ) with a mortality rate of $10 \%$ within 14 days follow up. Reflux esophagitis is an independent risk factor for post-banding ulcer bleeding that better to be treated before EVL.

\section{Funding: None.}

\section{Conflicts of interest: None.}

Ethical approval: The study was approved by the Institutional Review Board (IRB) of the Faculty of Medicine, Zagazig University. The patient gave a written informed consent for the procedure of upper endoscopy and EVL after explaining the risk/benefit ratio as well as the expected hazards and interventions and other measures.

\section{REFERENCES}

1. Garcia-Tsao G, Sanyal AJ, Grace ND, Carey W. Prevention and management of gastroesophageal varices and variceal hemorrhage in cirrhosis. Hepatology 2007; 46: 922-38.

2. Jensen DM. Endoscopic screening for varices in cirrhosis: findings, implications, and outcomes. Gastroenterology 2002; 122: 1620-30.

3. .3 De Franchis R. Evolving Consensus in Portal Hypertension Report of the Baveno IV Consensus Workshop on methodology of diagnosis and therapy in portal hypertension. $J$. Hepatol 2005; 43(1):167-76.

4. Polski JM, Brunt EM, Saeed ZA. Chronology of histological changes after band ligation of esophageal varices in humans. Endoscopy 2001, 33:443-7.

5. Tait IS, Krige JE, Terblanche J. Endoscopic band ligation of oesophageal varices. Br. J. Surg. 1999, 86: 437-46.

6. Saltzman JR, Arora S. Complications of esophageal variceal band ligation. Gastrointest. Endosc. 1993; 39: 203-5.

7. Schmitz RJ, Sharma P, Badr AS, Qamar MT, Weston AP. Incidence and management of esophageal stricture formation, ulcer bleeding, perforation, and massive hematoma formation from sclerotherapy versus band ligation. Am. J. Gastroenterol. 2001, 96: 437-41.

8. Petrasch F, Grothaus J, Mossner J, Schiefke I, Hoffmeister A. Differences in bleeding behavior after endoscopic band ligation: a retrospective analysis. BMC Gastroenterol. 2010; 10:5.

9. Bambha K, Kim WR, Pedersen R, Bida JP, Kremers WK, Kamath PS. Predictors of early rebleeding and mortality after acute variceal haemorrhage in patients with cirrhosis. Gut 2008; 57:814-20.

10. Vanbiervliet G, Giudicelli-Bornard S, Piche T, Berthier F, Gelsi E, Filippi J. et al. Predictive factors of bleeding related to post-banding ulcer following endoscopic variceal ligation in cirrhotic patients: a case-control study. Aliment. Pharmacol. Ther, 2010; 32:225-32.

11. Mishin I, Dolghii A. Early spontaneous slippage of rubber bands with fatal bleeding: a rare complication of endoscopic variceal ligation. Endoscopy 2005; 37:275-6.

12. Toyoda H, Fukuda Y, Katano Y, Ebata M, Nagano K, Morita K. et al. Fatal bleeding from a residual vein at the esophageal ulcer base after successful endoscopic variceal ligation. J Clin. Gastroenterol. 2001; 32:158-60.

13. Li P, Zhang ST, Yu ZL, Yu YZ, Ji M, Yu L. et al. Analysis of the risk factors in early rebleeding after endoscopic variceal ligation. Zhonghua Xiaohua Neijing Zazhi 2006; 23: 23-6. 
14. Aubé C, Oberti F, Korali N, Namour MA, Loisel D, Tanguy JY. et al. Ultrasonographic diagnosis of hepatic fibrosis or cirrhosis. J Hepatol 1999; 30(3): 472-8.

15. Cho E, Jun $\mathrm{CH}$, Cho SB, Park $\mathrm{CH}$, Kim HS, Choi SK. et al. Endoscopic variceal ligation-induced ulcer bleeding; What are the risk factors and treatment strategies? Medicine (Baltimore). 2017; 96(24):e7157.

16. Cárdenas A, Ginès P, Uriz J, Bessa X, Salmerón JM, Mas A. et al. Renal failure after upper gastrointestinal bleeding in cirrhosis: incidence, clinical course, predictive factors, and short-term prognosis. Hepatology 2001; 34(4 Pt 1):671-6.

17. Yamada S, Wongwanakul P. Randomized controlled trial of high dose bolus versus continuous intravenous infusion pantoprazole as an adjunct therapy to therapeutic endoscopy in massive bleeding peptic ulcer. J Med Assoc Thai 2012; 95(3):349-57.

18. Martí-Carvajal AJ, Solà I. Vitamin K for upper gastrointestinal bleeding in people with acute or chronic liver diseases. Cochrane Database Syst Rev 2015; (6): CD004792 .

19. Garcia-Tsao G, Abraldes JG, Berzigotti A and Bosch J. Portal hypertensive bleeding in cirrhosis: Risk Stratification, diagnosis, and management: 2016 practice guidance by the American Association for the study of liver diseases. Hepatology 2017; 65(1): 310-35.

20. EASL clinical practice guidelines on the management of ascites, spontaneous bacterial peritonitis, and hepatorenal syndrome in cirrhosis. J. Hepatol. 2010, 53(3): 397-417.

21. Hausman LM, Reich DL. Providing safe sedation/analgesia: an anesthesiologist's perspective. Gastrointest Endoscopy 2008; 44: 217-31.

22. Wai C. A simple noninvasive index can predict both significant fibrosis and cirrhosis in patients with chronic hepatitis C. Hepatology 2003; 38(2): 518-26.

23. Pugh RN, Murray-Lyon IM, Dawson JL, Pietroni MC, Williams R. Transsection of the oesophagus for bleeding oesophageal varices. Br J Surg. 1973; 60(8):646-9.
24. Malinchoc M, Kamath PS, Gordon FD, Peine CJ, Rank J, ter Borg PC. A model to predict poor survival in patients undergoing transjugular intrahepatic portosystemic shunts. Hepatology 2000; 31(4): 864-71.

25. Thakeb, F.; Zakaria, M.; Hunter, M. Mousa A, Atta A, El-Rooby A. et al. (1988): A study of the oesophagus by endoscopy and radiology after sclerotherapy. In Thakeb F. and Zakaria S. (eds.). Gastrointestinal Endoscopy: an Egyptian view, El-Sona El-Mohamadia, Egypt, 1988; P: 51.

26. Lundell LR, Dent J, Bennett JR, Blum AL, Armstrong D, Galmiche JPet al. Endoscopic assessment of oesophagitis: clinical and functional correlates and further validation of the Los Angeles classification. Gut. 1999; 45(2):17280.

27. Sinclair M, Vaughan R, Angus BW, Gow PJ, Parker F, Hey P. et al. Risk factors for bandinduced ulcer bleeding after prophylactic and therapeutic endoscopic variceal band ligation. Eur. J. Gastroenterol. Hepatol. 2015; 27: 928-32.

28. Shendy SM,Elnaggar MK, Salem HM, ElTalkawy MD, Saleem AA, Abu Taleb H. Incidence and risk factors contributing for early variceal rebleeding after esophageal variceal ligation Sch. J. App. Med. Sci. 2015; 3(3G): 1553-9.

29. Yang MT, Chen HS, Lee HC, Lin CL. Risk factors and survival of early bleeding after esophageal variceal ligation. Hepatogastroenterology 2007; 54: 1705-9.

30. Xu L, Ji F, Xu Q, Zhang M. Risk factors for predicting early variceal rebleeding after endoscopic variceal ligation. World $J$. Gastroenterol. 2011; 17(28): 3347-52 .

31. Shaheen NJ, Stuart E, Schmitz SM, Mitchell KL, Fried MW, Zacks S. et al. Pantoprazole reduces the size of post banding ulcers after variceal band ligation: A randomized, controlled trial: Hepatology 2005; 588 .

32. Kang SH, Yim HJ, Kim SY. Proton Pump Inhibitor Therapy Is Associated With Reduction of Early Bleeding Risk After Prophylactic Endoscopic Variceal Band Ligation: A Retrospective Cohort Study. Medicine 2016; 95(8):e2903. 